DEMOGRAPHIC RESEARCH

VOLUME 36, ARTICLE 45, PAGES 1361-1398

PUBLISHED 27 APRIL 2017

http://www.demographic-research.org/Volumes/Vol36/45/

DOI: 10.4054/DemRes.2017.36.45

Research Article

The convergence of second-generation

immigrants' fertility patterns in France:

The role of sociocultural distance between

parents' and host country

\title{
Ariane Pailhé
}

This publication is part of the Special Collection on "Childbearing among the Descendants of Immigrants in Europe," organized by Guest Editors Hill Kulu and Tina Hannemann.

\section{C2017 Ariane Pailhé.}

This open-access work is published under the terms of the Creative Commons Attribution NonCommercial License 2.0 Germany, which permits use, reproduction \& distribution in any medium for non-commercial purposes, provided the original author(s) and source are given credit.

See http:// creativecommons.org/licenses/by-nc/2.0/de/ 


\section{Contents}

1 Introduction 1362

2 The French context 1363

2.1 Descendants of immigrants in France 1363

2.2 Fertility in France 1364

2.3 Immigrant fertility in France 1364

3 Theoretical framework 1365

$4 \quad$ Data and method 1369

4.1 Data 1369

4.2 Method 1371

4.3 Control variables 1372

$5 \quad$ Results 1373

5.1 Timing of the first birth 1373

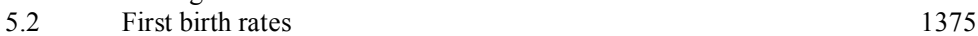

5.3 Second birth 1378

$5.4 \quad$ Third birth 1380

5.5 Effect of culture and educational level by origin 1382

$6 \quad$ Conclusion and discussion 1383

$7 \quad$ Acknowledgements 1386

$\begin{array}{ll}\text { References } & 1387\end{array}$

Appendix 1393 


\title{
The convergence of second-generation immigrants' fertility patterns in France: The role of sociocultural distance between parents' and host country
}

\author{
Ariane Pailhé ${ }^{1}$
}

\begin{abstract}
BACKGROUND

The fertility of immigrants' descendants is an important topic for demographers, since it affects the structure of the future population. However, little attention has been devoted to the fertility behaviour of the second generation in Europe.
\end{abstract}

\section{OBJECTIVE}

This study analyses the degree to which fertility of the descendants of immigrants is similar to that of French natives. It evaluates the extent to which the observed differences arise from the sociocultural distance between parents' country and host country and from structural determinants.

\section{METHODS}

We analyse the transition to first, second, and third births among different groups of immigrants' daughters (from the Maghreb, sub-Saharan Africa, Turkey, and Southeast Asia), and compare them to native-born women using discrete-time logistic regressions. The data is drawn from the Trajectories and Origins Survey (2008), which oversamples immigrants and their descendants.

\section{RESULTS}

We show a convergence towards French standards that differs across groups of origin. Women of Southeast Asian descent deviate from the fertility pattern of their parents, while those of Turkish descent preserve their parents' cultural heritage. These different paths of adaptation between groups partly reflect cultural distance between parents' country and host country. They also depend on family social capital, family structure, and family values. Access to a higher level of education is a crucial factor in erasing differences between groups.

\section{CONCLUSIONS}

The fertility behaviour of most groups of descendants of immigrants is converging

\footnotetext{
${ }^{1}$ Institut national d'études démographiques (INED), France. E-Mail: pailhe@ined.fr.
} 
Pailhé: The convergence of second-generation immigrants' fertility patterns in France

towards that of French natives. Cultural factors have much less influence on childbearing patterns than on union formation.

\section{Introduction}

There is a growing body of literature analysing the life trajectories of the descendants of postwar immigrants. Various topics have been investigated: for example, their educational attainment, employment trajectories, and partnership formation (Alba 2005; Meurs, Pailhé, and Simon 2006; Crul, Schneider, and Lelie 2012; Milewski 2010). However, little attention has been devoted to the fertility behaviour of the second generation in Europe (De Valk and Milewski 2011; Sobotka 2008).

Immigrant descendants' fertility is subject to multiple influences. An intergenerational transmission of fertility behaviour is usually observed, in terms of both level and timing of births (Barber 2001; Steenhof and Liefbroer 2008). This transmission may be different for descendants of immigrants who have been socialised into their parents' specific values; it may also be affected by the norms and standards of the country where they were born and socialised (De Valk and Milewski 2011). The degree of adaptation to the dominant fertility behaviour in the host society may vary according to origin, depending on the cultural distance between the parents and the host country (Adserà and Ferrer 2014; Kulu et al. 2017). It may also depend on the way the countries of settlement incorporate immigrants and their descendants (Milewski 2011).

While fertility behaviours have been extensively examined for first generation immigrants in France (Tribalat 2005; Toulemon 2004), little attention has been paid to the descendants of immigrants, who make up a sizeable and growing fraction of the French population (about 10\%, INSEE 2012). This article explores whether and how much descendants of immigrants follow the fertility behaviour of the native population. First, it analyses to what degree the children of immigrants have assimilated hostcountry norms in terms of level and timing of first childbearing and propensity to have a second and third child. Second, it evaluates the extent to which the observed differences arise from the sociocultural distance between parents' country and host country and from structural determinants.

We analyse the transition to first, second, and third births among different groups of female descendants of immigrants, and we compare them to native French women. These parity-specific transitions are analysed because each has its own rationale in France. Entry into parenthood is a key stage in the transition to adulthood, and it is closely related to completing education, forming a couple, and starting employment (Ferrari and Pailhé 2017). Transition to a second birth is fairly uniform, given the 
strong two-child family norm (Régnier-Loilier 2006), while transition to a third birth is more related to cultural background (Pailhé and Solaz 2013). Several groups whose cultural origins differ greatly from the host country are selected, most of them having high levels of fertility: from the Maghreb, sub-Saharan Africa, Turkey, and Southeast Asia. Our research design uses a unique dataset that oversamples immigrants and their descendants: it is drawn from the Trajectories and Origins Survey, conducted in 2008.

\section{The French context}

\subsection{Descendants of immigrants in France}

France's history of mass immigration began in the mid-19th century, and continued throughout the 20th century even after restrictive immigration policies were introduced following the economic downturn of the 1970s. In 2010, immigrants accounted for $10.7 \%$ of the population of mainland France. Descendants of immigrants totalled about 4.5 million in 2008, which represents about $10 \%$ of the total population of the country (INSEE 2012). The descendants of immigrants from Southern Europe (Italy, Spain, and Portugal) are most numerous, followed by those of immigrants from the Maghreb (Algeria, Morocco, and Tunisia). Immigrants from Southeast Asia, Turkey, and subSaharan Africa are more recent and less numerous, so their second generation is smaller (Table 1).

Table 1: Distribution of adult descendants of immigrants by parents' place of birth, 2008

\begin{tabular}{lcc}
\hline & Thousands & $\%$ \\
\hline Italy & 880 & 20 \\
Other EU-27 countries & 780 & 17 \\
Algeria & 640 & 14 \\
Spain & 580 & 13 \\
Portugal & 450 & 10 \\
Morocco & 310 & 7 \\
Other African countries & 200 & 4 \\
Tunisia & 180 & 4 \\
Other European countries & 160 & 4 \\
Cambodia, Laos, Vietnam & 90 & 2 \\
Turkey & 80 & 2 \\
Other Asian countries & 80 & 2 \\
Americas, Oceania & 60 & 1 \\
\hline Total & 4,480 & 100 \\
\hline
\end{tabular}

Source: INSEE 2012 


\subsection{Fertility in France}

As elsewhere in Europe, in France entry into parenthood is increasingly delayed and the timing of fertility is rapidly changing (Toulemon, Pailhé, and Rossier 2008). The fertility schedule is moving steadily to higher ages and the mean age at childbirth is continuing to rise. The mean age at first childbirth has increased since the mid-1970s, rising from 23.9 years in 1975 to 28.1 years in 2010. This increase is a result of both a decrease in fertility at young ages (before 25) and an increase at ages 28 and over (INSEE, bilan démographique).

However, unlike in the other European countries, this postponement seems to have little impact on completed fertility. France is one of Europe's most fertile countries. In 2008, with 1.99 children per woman on average, France ranked second in Europe, behind Ireland. Since the end of the 1990s, France has stood apart from many other European countries: fertility began to increase clearly from 1996, and the period total fertility rate has remained stable at above 1.9 since 2000 .

The proportion of childless women has remained very low: only $11 \%$ of women born in 1970 will remain childless, and "the probability of a progression to a second, a third and a fourth child has not changed since 1975" (Toulemon, Pailhé, and Rossier 2008). All in all, a higher proportion of women give birth to a first child in France than in other European countries, and the rates are similar for second and third births (Prioux 2003). Finally, the two-child family is the norm (Régnier-Loilier 2006): 41\% of women born in 1960 have two children.

This relatively high level of fertility is related to a tradition of familialism, i.e., an ideology that promotes the family as an institution (Revillard 2006), and a generous and diverse family policy, i.e., a combination of allowances, tax deductions, and childcare facilities that make it possible to combine family and work (Toulemon, Pailhé, and Rossier 2008).

\subsection{Immigrant fertility in France}

Many migrants come from high fertility countries where age at first birth is low, which is especially the case in sub-Saharan Africa (Table A-1). Most immigrant women living in France, especially those born outside Europe but not in Asia, have more children than French natives (Table 2). According to census data, immigrant women account for less than one in five births. Since they only represent $12 \%$ of women aged 15 to 50 the contribution of immigrants to fertility is low (Héran and Pison 2007): without women born abroad, the TFR would only be 0.1 lower (Pla and Beaumel 2012). 
Table 2: $\quad$ TFR by country of birth for immigrants in France, 2008

\begin{tabular}{ll}
\hline & TFR \\
\hline Spain, Italy, Portugal & 1.8 \\
Other European countries & 2.0 \\
Algeria & 3.5 \\
Morocco, Tunisia & 3.3 \\
Other African countries & 2.9 \\
Turkey & 2.9 \\
Other Asian countries & 1.9 \\
Americas, Oceania & 2.6 \\
All immigrants & 2.6 \\
\hline Total & 1.9 \\
\hline
\end{tabular}

Source: INSEE, Population census

Little is known about the fertility of second-generation immigrants in France, since it is not possible to identify this population category in the French census. Before the 2000s only specific surveys such as the Mobilité géographique et insertion sociale (geographical mobility and social integration, MGIS) survey, conducted by INED in conjunction with INSEE in 1992, specifically identified the descendants of immigrants. Since then, many more surveys have collected information that permits this identification, but few of them have large enough samples to compare behaviours across groups of origin. Using the recent Trajectories and Origins Survey, Pailhé and Hamel (2015) show that the median age at first childbirth of second-generation immigrants is as high as - and even higher than - that of natives.

\section{Theoretical framework}

Competing hypotheses have been developed concerning the childbearing patterns of descendants of immigrants (Hervitz 1985; Kulu 2005; Milewski 2007). As immigrants may be influenced by their parents' norms and standards and by the norms and standards in their country of residence, both socialization and assimilation hypotheses may explain their fertility behaviour.

The socialization hypothesis considers that exposure to certain norms, preferences, and values during childhood (i.e., those of the parents) have long-lasting effects and are dominant in shaping the fertility behaviour of the second generation (Barber 2001; Rijken and Liefbroer 2009). Due to family socialization, specific family values and norms may persist among immigrants' descendants: it has been shown that ideas about the appropriate timing and sequencing of family formation among immigrants' 
descendants differ from those found among the native population (de Valk and Liefbroer 2007). In particular, childbearing is expected to start soon after marriage. Thus, according to the socialization hypothesis, intergenerational continuities in fertility behaviour may be observed and fertility patterns should be close to those of the country of origin: when the parents come from societies where childbearing occurs at younger ages, their descendants' age at first childbearing can be expected to be younger and more closely linked to union formation than that of the native population.

By contrast, the assimilation or adaptation hypothesis emphasizes the adaptation of behaviours to the environment and norms of the host country (Gordon 1964). The behaviours of descendants of immigrants are shaped by the values and norms of the dominant culture, through schooling, the media, and social contacts outside the group of origin (Huschek, Liefbroer, and De Valk 2010; Collet and Santelli 2012). According to the assimilation hypothesis, differences with respect to majority group fertility merely reflect differences in socioeconomic characteristics between groups. These differences are temporary and should disappear when the socioeconomic characteristics of descendants of immigrants catch up with those of the majority group. The fertility behaviours of the second generation should thus converge with those in the host country.

However, according to the minority status hypothesis, minority groups may have different fertility levels that result from feelings of insecurity and perceived marginality associated with minority group status (Goldscheider and Uhlenberg 1969; Halli 1989; Chabé-Ferret and Melindi Ghidi 2013). Some minorities face specific barriers in education and employment (Meurs, Pailhé, and Simon 2006; Brinbaum, Meurs, and Primon 2015). To enhance their position they may compensate for their disadvantages by deferring or limiting childbearing; or, alternatively, by refusing to assimilate dominant value systems and opting for higher fertility. Thus the fertility level and timing of minorities with disadvantaged status may differ from those of natives, depending on their expected opportunities for upward mobility. The more recent literature on immigrant integration has stressed that the assimilation of descendants of immigrants is not uniform, but segmented: they follow several paths of adaptation based on disparities in their parents' social and human capital, family structure, and modes of incorporation in the host society (Portes, Fernandez-Kelly, and Haller 2009). Thus, the convergence of fertility patterns towards that of natives occurs at various rates across groups of origin, depending on the parents' cultural characteristics and on specific structural impediments acting on their children (Portes and Zhou 1993; Portes, Fernandez-Kelly, and Haller 2009).

Empirical studies have found a general trend of converging fertility patterns across generations of immigration. This adjustment to host country behaviour among children of immigrants has been found in Germany (Milewski 2007, 2010), Sweden (Scott and 
Stanfors 2011), the Netherlands (Garssen and Nicholaas 2008), the UK (Dubuc 2012; Kulu and Hannemann 2016), and France (Pailhé and Hamel 2015; Afulani and Asunka 2015). The convergence of fertility patterns has been found to be lower for those with Turkish origins (Scott and Stanfors 2011; Pailhé and Hamel 2015), given their strong attachment to the "Turkish family culture" (Milewski 2010). The differing extent of adhesion to parental vs. country childbearing norms depends on the social and cultural context of the destination country (Kulu et al. 2017). Turkish descendants in countries where fertility is low tend to postpone fertility compared to those in countries where fertility is higher (Milewski 2011), which is a sign that they adjust their behaviours to the environment and norms of the society of settlement. More generally, it has been shown that immigrant assimilation takes time and occurs over several generations (Alba and Nee 2003).

Immigrants in France come from high-fertility countries were traditional values emphasize the importance of religion, parent-child ties, and traditional family values, especially in the Maghreb, sub-Saharan Africa, and Turkey (Inglehart and Welzel 2005). Assuming that immigrant parents are influenced by the religious/familialistic models prevailing in their country of origin, and that family socialization is a key driver of childbearing, we formulate the following research hypotheses:

H1a. Children of immigrants have higher and earlier fertility than the native French.

H1b. Due to the strong two-child family norm in France, the main differences between groups are found in the transitions to first and third births. Children of immigrants are more likely to have their first child earlier and to have a third child than the native French.

Childbearing patterns are likely to differ across groups of origin. Behaviours are expected to be closer to those of the native population among groups whose parents come from countries that are culturally closer to the host country. Since the normative constraints are stronger in the traditions of North and sub-Saharan Africa and Turkey than in those of Southeast Asia, then:

H1c. The fertility behaviour of descendants of immigrants from Southeast Asia is closer to that of French natives than to that of descendants of immigrants from the other selected countries: children of immigrants from Southeast Asia are likely to have a lower propensity to have children than others and to delay motherhood.

Being raised in a religious family tends to encourage childbearing and early motherhood (Michaël and Tuma 1985; Régnier-Loilier and Prioux 2008). In particular, 
the Muslim tradition encourages simultaneous parental homeleaving and marriage, quickly followed by first birth (Collet and Santelli 2012). Family structure, such as the number of siblings, acts on childbearing in the same way: having grown up in a large family usually correlates positively with family size, since it may lead to a preference for large families. It may also indicate that the respondent was raised in a family with strong family values (Michaël and Tuma 1985). Descendants of immigrants have often grown up in larger families, with stronger religious beliefs than natives: thus we put forward the following hypotheses:

H2a. Daughters of immigrants raised in less religious and smaller families adapt more readily to dominant fertility behaviours.

$\mathrm{H} 2 \mathrm{~b}$. Religiosity has a stronger positive effect on the fertility of children of immigrants from the Muslim countries (the Maghreb and Turkey) than it does for those from the other non-Muslim countries.

H2c. Intergenerational transmission of fertility behaviour is higher for groups from countries where traditional values emphasize the importance of parent-child ties and traditional family values; i.e., higher in the Maghreb, sub-Saharan Africa, and Turkey than in Southeast Asia.

The socioeconomic status (parental income, educational level, occupation) of the family of origin also affects fertility patterns. Research has shown that age at first childbirth is higher and the number of children is lower when the parents have a high educational level (Barber 2001). Parental socioeconomic status shapes life goals and defines the economic resources available to young adults. Individuals from families who cannot afford to support their pursuit of postsecondary education may perceive few alternatives to the immediate adoption of adult social roles (Lee 2013). Own education is one of the most important determinants of childbearing behaviours (Ní Bhrolcháin and Beaujouan 2012; Wood, Neels, and Kil 2014). A higher level of education increases the opportunity cost of childbearing - the parent must forego income or career opportunities to care for the child - and thus encourages postponement of childbearing (Becker 1981). Education also strongly shapes both individual preferences and age at first partnership (Furtado 2012; Ní Bhrolcháin and Beaujouan 2012). In the case of immigrants' descendants, access to higher education may reduce feelings of insecurity and perceived marginality associated with minority group status. Individuals with higher education are also likely to distance themselves from parental norms and to converge with native norms. We expect to find that educational attainment is a key factor in shaping fertility behaviours; therefore we hypothesize: 
H3. Access to higher levels of education erases differences between groups. The higher educational level of the Southeast Asian second generation reinforces the convergence towards French fertility norms. Conversely, due to their lower educational background, second-generation Turks experience a lower convergence; i.e., earlier childbearing and higher fertility relative to the French population.

\section{Data and method}

\subsection{Data}

The data we use is drawn from the Trajectories and Origins $(\mathrm{TeO})$ survey, a nationally representative survey conducted in 2008 by the French Institute of Demographic Studies (INED) and the National Institute of Statistics and Economic Studies (INSEE). This unique survey investigates the living conditions and social trajectories of immigrants and second-generation immigrants living in France. Twenty-two thousand persons living in metropolitan France were interviewed, and immigrants and their descendants were oversampled, especially those from more recent regions of migration, such as Turkey, Southeast Asia, and sub-Saharan Africa (Beauchemin, Hamel, and Simon 2010). ${ }^{2}$ Native French and immigrants were 18-60 years old (cohorts 19481990), while descendants of immigrants were 18-50 years old (cohorts 1958-1990).

The survey contains retrospective biographical data concerning family and employment history, particularly years of childbirth. The survey also contains standard socioeconomic information and very detailed information on family background, e.g., parents' social class, religion, education level, number of siblings, language skills, etc.

Groups of immigrants are defined in detail: individual place of birth and nationality at birth, parents' place of birth and nationality at birth, year of arrival in France and reasons for arrival. Native French are defined as individuals born to two French-born parents. Descendants of immigrants are persons born in France with at least one immigrant parent. The following aggregated regions of origin are used: the Maghreb (Algeria, Tunisia, and Morocco), sub-Saharan Africa (Senegal, Mali,

\footnotetext{
${ }^{2}$ The TeO survey sample was constructed in a complex matching operation between data from the 2007 census, the permanent demographic sample (EDP), and the civil registration system. The census was used to find the names and addresses of the people to be surveyed, but since information on the parents' place of birth and citizenship of birth is not available in the French census, information on individuals' family origin (parents' place of birth) was obtained from the EDP and civil records. The response rate was $70 \%$ (Algava and Lhommeau 2015).
} 
Cameroon, Guinea, etc.), Southeast Asia (Vietnam, Cambodia, and Laos), and Turkey. ${ }^{3}$ Women with missing information, first childbirth before age 15 , or with inconsistent dates in their life history were excluded from the analysis. Our analytic samples are different for each outcome. The sample for the first birth comprises 3,963 women, and for the second birth 2,000 women. For the transition to the third birth, Turkish, Southeast Asian and Sub-Saharan African second generations are excluded from the analysis, since the number of events is too low for these groups (Table 3). Our sample includes 1,188 women. Table 3 displays the sample size for each group and the number of births.

Table 3: Sample size and number of events

\begin{tabular}{lcccccc}
\hline & 2G Maghreb & $\begin{array}{c}\text { 2G Sub- } \\
\text { Saharan Africa }\end{array}$ & $\begin{array}{c}\text { 2G Southeast } \\
\text { Asia }\end{array}$ & 2G Turkey & Native & Total \\
\hline No child & 690 & 326 & 206 & 149 & 592 & 1,963 \\
1st child & 665 & 117 & 67 & 85 & 1,066 & 2,000 \\
2nd child & 434 & 57 & 30 & 51 & 754 & 1,326 \\
3rd child & 192 & 19 & 8 & 14 & 265 & 498 \\
N & 1,355 & 443 & 273 & 234 & 1,658 & 3,963 \\
\hline
\end{tabular}

Table A-2 gives the characteristics of each group. Descendants of immigrants are younger on average than the French natives. Nearly three-quarters of descendants of immigrants from Europe are over 35, whereas about half of descendants of immigrants from Turkey, Southeast Asia, or sub-Saharan Africa are under 25. Among descendants of immigrants, women from the Maghreb are older: their mean age is 30.6 years versus around 25 for the other groups.

Compared to the native population, the four selected groups differ significantly in terms of educational level and background: they are less educated, come more frequently from a lower social category, and were born in larger and more religious families. Women from the Turkish second generation are the least-educated and the French language was less frequently spoken at home during their childhood. By contrast, women of Southeast Asian descent are more frequently highly educated: the share of women with a tertiary level of education (41\%) is even higher than that of the French natives. Compared to the other groups of descendants of immigrants, Southeast Asians are less often raised in large families (most of them have 2 or 3 siblings), religion is less important in their education, and they come from a more advantaged social background. The sub-Saharan and Maghrebian second generations are

\footnotetext{
${ }^{3}$ Due to small case numbers, women with two immigrant parents from different groups (e.g., a father from the Maghreb and a mother from sub-Saharan Africa) were excluded. The most common situation is one parent from the Maghreb and the other parent from sub-Saharan Africa, but only 8 women are in this group.
} 
intermediate between these two groups and quite close in terms of educational level. Like those of Turkish descent, they are more often from a low social category and from families marked by religiosity. They also come from larger families and their parents, being from former French colonies, speak the French language more frequently.

\subsection{Method}

To identify the specific effect of origin on fertility, we estimate multilevel discrete-time logistic regressions (Allison 1982). Childless women are followed from age 15, and cases are censored at the interview date or at age 40 when no birth is reported. For second (third) births, only women who reported a first (second) birth are at risk. They are followed from the year of this first (second) birth and censored at the interview date or 15 years after the first (second) birth. Since the number of events is very small for Turkish, sub-Saharan, and Southeast Asian descendants of immigrants, the transition to the third birth is analysed only for natives and the Maghrebian second generation.

The data was organized into person-year files: the observations were repeated for each year in which the person was likely to experience the event (birth of the first, second, or third child). The dependent variable takes a value of 0 if the event does not occur in year $t$, and a value of 1 in the year in which the woman conceives her first child. For individuals not experiencing the event before the interview, the dependent variable takes a value of 0 for every year until censoring. This strategy yielded 40,462 person-years for first birth, 9,492 person-years for second birth, and 7,878 for third birth.

The discrete-time hazard function $h_{i j}(t)$ is the probability of event $y$ in time period $t$ during episode $i$ of individual $j$, given the event has not occurred before start of $t$.

$$
h_{i j}(t)=\operatorname{Pr}\left(y_{i j}(t)=1 \mid \operatorname{Pr}\left(y_{i j}(t)-1=0\right)\right.
$$

With a logistic specification, it becomes:

$$
\operatorname{logit}\left[h_{i j}(t)\right]=\propto(t)+\beta x_{i j}(t)+u_{j}
$$

$\alpha(t)$ is the baseline hazard function, $x_{i j}(t)$ are covariates, and $u_{j}$ a random effect representing unobserved characteristics of individual $j$ (common to all episodes). 


\subsection{Control variables}

The same set of control covariates is used to analyse the transition to the first, the second, and the third birth, with the covariates being added step by step in order to analyse how the specific effect of origin is related to these covariates. Model 1 assesses the gross effect of different origins on birth hazard. It controls for migration background, birth cohort, and hazard rate. Dummy variables for each group of origin are introduced (the reference category being native women), as well as a separate dummy variable indicating whether the woman is the child of a mixed couple, i.e., one parent is an immigrant and the other native-born. Two birth cohorts are distinguished: 1958-1974 and 1975-1990. Since the hazard rate varies with time, we split the sample into five age categories $(15-17,18-21,22-25,26-29,30-40)$ for first births, four year categories $(0-1,2-3,3-6,7-15)$ for second births, and three categories $(0-1,2-5,6-$ 15) for third births. In order to test whether timing of first childbearing differs across origins (H1), we introduce interactions between origin groups and the baseline hazard in an alternative specification (Model 1b).

In order to control for a link between union formation and childbearing, Model 2 controls for partnership status, i.e., three time-varying dummy variables indicating whether the woman started living in a nonmarital union, in a marital union, and whether this first union is mixed. These variables are built from the year of first cohabiting union lasting at least six months and the year of first religious or civil marriage. A mixed union is defined as union with a native for descendants of immigrants, and as a union with an immigrant or a descendant of immigrants for native French people. These time-dependent variables are lagged by one year to evaluate their effect on the conception of the child. Two additional variables related to the first birth are added into the models for second and third births: age at first birth and sex of the previous child(ren), to take account of the possible preference for children of different sexes (Hank and Kohler 2003).

Model 3 controls for some background variables to test if the family's socioeconomic and cultural position influences childbearing. Social background is taken into account through parents' social class (at least one parent unskilled manual worker, clerical worker, other). Culture is measured through the importance of religion in home upbringing (rather or very important, not or barely important). We use this last variable rather than religion, since the type of religion is correlated to the country of origin. We also control for the number of siblings (less than two, two or three, four and more $)^{4}$ and for the main language spoken by parents during the woman's childhood (only French, French and foreign, only foreign), since this may be an indicator of integration into the host society (Gordon 1964).

\footnotetext{
${ }^{4}$ This corresponds to the number of brothers and sisters ever had, including half-brothers and half-sisters.
} 
Model 4 controls for the current level of education. It is thus introduced with four dummy variables: 1) no education, primary, or lower secondary general education, 2) lower secondary vocational education, 3) upper secondary education, and 4) postsecondary education. Finally, the timing of childbearing is usually strongly correlated with having completed education and with employment status (Mills, Blossfeld, and Klijzing 2005). Model 4 also controls for labour market status: whether the respondent is still in education or has been employed in a stable job. These timedependent variables, computed for each calendar year using the date of leaving education and of first job lasting at least one year, are lagged by one year. Being in education and having a child are not very compatible: the majority of women in France wait until they have completed education and found a stable job before entering motherhood (Pailhé and Solaz 2012; Ciganda 2015).

To test our hypotheses $\mathrm{H} 2 \mathrm{a}$ and $\mathrm{H} 2 \mathrm{~b}$, we introduce into Model 4 interactions between origin groups and cultural background variables (religiosity and number of siblings). To test hypothesis $\mathrm{H} 3$ we introduce interactions between origin groups and education level. From these models we compute and display marginal probabilities that are easier to interpret.

\section{Results}

\subsection{Timing of the first birth}

The transition to first birth follows different patterns according to origin (Table 4). It occurs faster for female descendants of Turkish immigrants. Their median age at first birth is 24 years, four years before native French women. By contrast, descendants of sub-Saharan African immigrants tend to postpone childbearing. It is not until age 32 that $50 \%$ of women whose parents come from sub-Saharan Africa have become firsttime mothers, with $47 \%$ having a first child by age 30 . Descendants of immigrants from Southeast Asia also postpone childbearing when compared to the native population, although to a lesser extent. The median age at first childbirth for descendants of immigrants from the Maghreb is similar to that of native French women, but a lower proportion of the Maghrebian second generation are mothers by age 30. This later childbearing does not result in higher childlessness, however. By age 40 the share of childless women in the two groups converges. 
Pailhé: The convergence of second-generation immigrants' fertility patterns in France

Table 4: Proportion with a child at age 30 and median age at birth

\begin{tabular}{lcccccc}
\hline & \multicolumn{2}{c}{ Proportion with a first child by age (\%) } & \multicolumn{3}{c}{ Median age } \\
\cline { 2 - 7 } & Age 25 & Age 30 & Age 35 & Age 40 & First birth & Second birth $^{(\text {a) }}$ \\
\hline 2G Maghreb & 32 & 61 & 79 & 83 & 28 & 31 \\
2G Sub-Saharan Africa & 23 & 47 & 62 & 70 & 32 & 34 \\
2G Southeast Asia & 31 & 51 & 82 & - & 30 & 31 \\
2G Turkey & 54 & 70 & - & - & 24 & 26 \\
Native & 33 & 68 & 80 & 83 & 28 & 31 \\
\hline
\end{tabular}

Notes: Analyses adjusted using sampling weights; (a) For mothers

Source: Calculations based on TeO 2008

Introducing interactions between origin groups and the baseline hazard in Model $1 \mathrm{~b}$ (Figure 1) confirms that descendants of immigrants from Turkey enter motherhood at younger ages than French natives. Their probability of having a first child is significantly higher than that of natives at ages 18-21 and at ages 22-25, but lower after age 25. Conversely, daughters of immigrants from Southeast Asia are less likely than natives to have their first child at ages $22-29$, and more likely to do so after age 30 (with large confidence intervals, however).

\section{Figure 1: Odds of a first birth by origin and age}

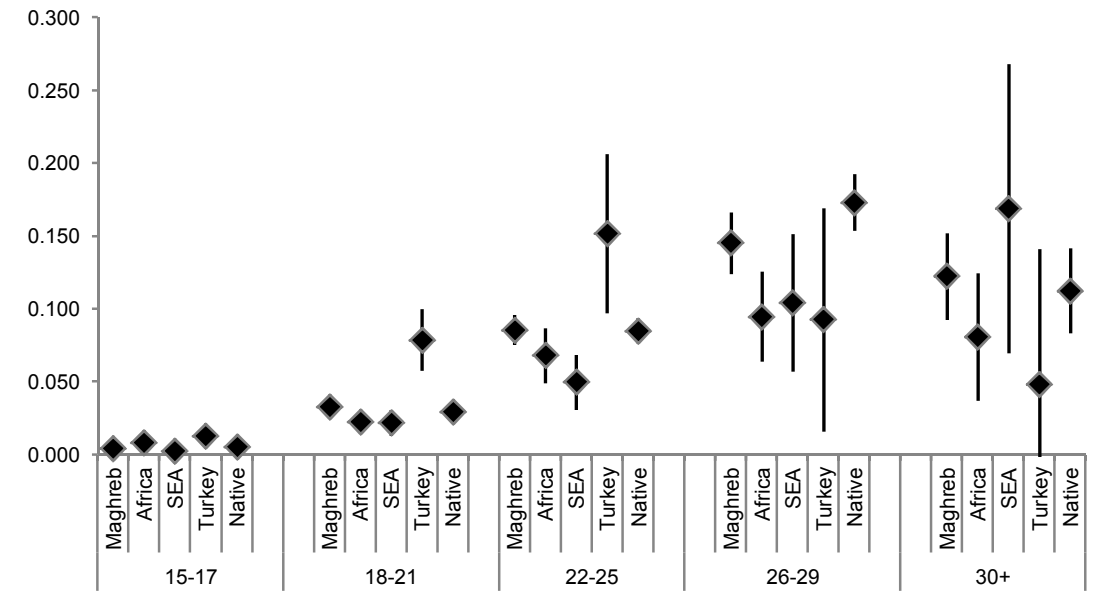

Notes: Odds computed from a multilevel discrete-time logistic regression of probability of first conception controlled for migration background, birth cohort, hazard rate, and interactions between origin groups and the baseline hazard (Model 1b); confidence intervals at $90 \%$

Source: Calculations based on $\mathrm{TeO} 2008$ 
For women of Maghrebian or sub-Saharan African descent, results differ from the descriptives displayed in Table 4 once partnership status is controlled for. Hence, their probability of entering motherhood is slightly higher than that of natives at ages 18-21 (not shown here), but with far fewer differences compared with Turks.

\subsection{First birth rates}

Table 5 presents the results of the multilevel discrete-time logistic regression estimates. For Turkish descendants of immigrants, the gross observed higher fertility comes from differences in group characteristics. Symmetrically, the lower fertility risks for those sub-Saharan descent are linked to their cultural background and socioeconomic characteristics. Conversely, daughters of Southeast Asian and Maghrebian immigrants still have lower first birth rates after controlling for partnership status, cultural background, or socioeconomic status.

The higher propensity for women of Turkish descent to have a first child compared to native French women (Model 1) decreases once partnership formation is controlled for (Model 2), meaning that part of their higher first birth rate is linked to their early union formation (see Pailhé 2015). Differentials in cultural background across groups of origin are key factors in shaping this gap. Hence, once religiosity, number of siblings, parents' social status, and language spoken are taken into account, there is no significant difference between the Turkish second generation and French natives (Model 3). Thus, the higher first birth rate for women of Turkish descent stems from the combination of an intergenerational transmission of family values and their early union formation, which are interrelated. The parameter for the Turkish second-generation origin becomes negative (but is still non-significant) when educational level and employment status are controlled for (Model 4), meaning that the raw higher first birth rate also comes from lower educational level.

Conversely, women whose parents come from Southeast Asia have a lower propensity to enter motherhood, whatever the specification. The gap in first birth rates between descendants of immigrants from Southeast Asia and native French is no longer significant after controlling for partnership formation (Model 2). This indicates that the lower propensity of Southeast Asian descendants to form a union decreases their firstbirth risks. As already mentioned in the previous section, childbearing is also highly dependent on union formation for descendants of sub-Saharan African immigrants. Hence, their risk of having a first child is lower, except in Model 2. When we do not control for partnership formation, descendants of immigrants from sub-Saharan Africa have a significant negative probability of having a first child and parameters are higher than in Model 1 (results not shown here, available on request). 
Pailhé: The convergence of second-generation immigrants' fertility patterns in France

Table 5: Multilevel discrete-time logistic regression of probability of first conception

\begin{tabular}{|c|c|c|c|c|}
\hline & Model 1 & Model 2 & Model 3 & Model 4 \\
\hline \multicolumn{5}{|c|}{ Migration background (ref= Native) } \\
\hline \multirow[t]{2}{*}{ 2G Maghreb } & -0.021 & $0.140^{*}$ & $-0.162^{*}$ & $-0.216^{\star *}$ \\
\hline & $(0.062)$ & $(0.074)$ & $(0.095)$ & $(0.100)$ \\
\hline \multirow[t]{2}{*}{ 2G Sub-Saharan Africa } & $-0.293^{\star *}$ & 0.160 & -0.131 & -0.086 \\
\hline & $(0.118)$ & $(0.141)$ & $(0.150)$ & $(0.158)$ \\
\hline \multirow[t]{2}{*}{ 2G Southeast Asia } & $-0.400^{\star \star \star}$ & -0.114 & $-0.369^{\star \star}$ & $-0.314^{*}$ \\
\hline & $(0.144)$ & $(0.152)$ & $(0.160)$ & $(0.163)$ \\
\hline \multirow[t]{2}{*}{ 2G Turkey } & $0.658^{\star \star \star}$ & $0.530^{\text {***}}$ & 0.172 & -0.051 \\
\hline & $(0.158)$ & $(0.148)$ & $(0.174)$ & $(0.183)$ \\
\hline \multicolumn{5}{|c|}{ Parental background (ref $=$ unmixed) } \\
\hline \multirow{2}{*}{$\begin{array}{l}\text { Descendant of mixed parental } \\
\text { background }\end{array}$} & -0.086 & 0.020 & $0.217^{*}$ & $0.218^{*}$ \\
\hline & $(0.090)$ & $(0.103)$ & $(0.113)$ & $(0.116)$ \\
\hline \multicolumn{5}{|l|}{ Birth cohort (ref = 1958-1974) } \\
\hline \multirow[t]{2}{*}{$1975-1990$} & $-0.215^{\star \star \star}$ & $-0.125^{\star \star}$ & -0.100 & 0.043 \\
\hline & $(0.058)$ & $(0.062)$ & $(0.063)$ & $(0.069)$ \\
\hline \multicolumn{5}{|l|}{ Age $(r e f=26-28)$} \\
\hline \multirow[t]{2}{*}{$15-17$} & $-3.416^{* * *}$ & $-1.293^{\star * *}$ & $-1.379^{* \star *}$ & $-1.360^{* * *}$ \\
\hline & $(0.149)$ & $(0.151)$ & $(0.151)$ & $(0.171)$ \\
\hline \multirow[t]{2}{*}{$18-21$} & $-1.652^{\star \star \star}$ & $-0.593^{\star * *}$ & $-0.686^{\star \star *}$ & $-0.833^{* * *}$ \\
\hline & $(0.097)$ & $(0.084)$ & $(0.086)$ & $(0.101)$ \\
\hline \multirow[t]{2}{*}{$22-25$} & $-0.644^{\star * \star}$ & $-0.384^{\star \star *}$ & $-0.429^{\star \star \star}$ & $-0.508^{\star \star *}$ \\
\hline & $(0.074)$ & $(0.072)$ & $(0.073)$ & $(0.076)$ \\
\hline \multirow[t]{2}{*}{$29+$} & $-0.255^{\star *}$ & $-0.254^{\star * *}$ & $-0.236^{\star \star}$ & $-0.201^{*}$ \\
\hline & $(0.112)$ & $(0.098)$ & $(0.099)$ & $(0.103)$ \\
\hline \multicolumn{5}{|l|}{ Partnership status (ref $=$ single) } \\
\hline \multirow[t]{2}{*}{ Married } & & $1.415^{\star \star \star}$ & $1.447^{\star \star \star}$ & $1.444^{* * *}$ \\
\hline & & $(0.068)$ & $(0.070)$ & $(0.073)$ \\
\hline \multirow[t]{2}{*}{ Cohabiting } & & $2.317^{\text {***}}$ & $2.314^{\text {***}}$ & $2.225^{\star * *}$ \\
\hline & & $(0.094)$ & $(0.094)$ & $(0.094)$ \\
\hline \multicolumn{5}{|c|}{$\begin{array}{l}\text { Type of union (ref = no partner or same } \\
\text { origin) }\end{array}$} \\
\hline \multirow[t]{2}{*}{ Mixed union } & & -0.042 & -0.042 & -0.018 \\
\hline & & $(0.079)$ & $(0.081)$ & $(0.085)$ \\
\hline \multicolumn{5}{|l|}{$\begin{array}{l}\text { Importance of religion in own } \\
\text { education (ref= Not or barely) }\end{array}$} \\
\hline \multirow[t]{2}{*}{ Rather or very important } & & & $-0.195^{\star \star *}$ & $-0.126^{*}$ \\
\hline & & & $(0.062)$ & $(0.065)$ \\
\hline \multicolumn{5}{|c|}{$\begin{array}{l}\text { Parents social class (ref= Higher than } \\
\text { unskilled) }\end{array}$} \\
\hline \multirow[t]{2}{*}{ Unskilled blue or white collar } & & & 0.009 & -0.059 \\
\hline & & & $(0.080)$ & $(0.082)$ \\
\hline \multicolumn{5}{|c|}{ Number of siblings (ref= Less than 2) } \\
\hline \multirow[t]{2}{*}{2 or 3} & & & $0.298^{\star \star \star}$ & $0.198^{* *}$ \\
\hline & & & $(0.073)$ & $(0.078)$ \\
\hline $4+$ & & & $0.636^{\star \star \star}$ & $0.440^{* * *}$ \\
\hline & & & $(0.093)$ & $(0.097)$ \\
\hline
\end{tabular}


Table 5: (Continued)

\begin{tabular}{|c|c|c|c|c|}
\hline & Model 1 & Model 2 & Model 3 & Model 4 \\
\hline \multicolumn{5}{|c|}{$\begin{array}{l}\text { Language spoken by parents (ref= } \\
\text { Only French / French and foreign) }\end{array}$} \\
\hline \multirow[t]{2}{*}{ Only foreign } & & & $0.309^{* \star *}$ & $0.272^{\star \star}$ \\
\hline & & & $(0.118)$ & $(0.120)$ \\
\hline \multicolumn{5}{|c|}{$\begin{array}{l}\text { Educational level (ref= No } \\
\text { qualifications) }\end{array}$} \\
\hline \multirow[t]{2}{*}{ Lower vocational } & & & & $-0.495^{\star \star \star}$ \\
\hline & & & & $(0.104)$ \\
\hline \multirow[t]{2}{*}{ Secondary } & & & & $-0.768^{\star \star \star}$ \\
\hline & & & & $(0.107)$ \\
\hline \multirow[t]{2}{*}{ Higher } & & & & $-0.987^{\star \star \star}$ \\
\hline & & & & $(0.109)$ \\
\hline \multicolumn{5}{|c|}{ Education status (ref=in education) } \\
\hline \multirow[t]{2}{*}{ No longer in education } & & & & $0.991^{\star \star \star}$ \\
\hline & & & & $(0.123)$ \\
\hline \multicolumn{5}{|c|}{$\begin{array}{l}\text { Labour market status (ref.= Not in } \\
\text { stable employment) }\end{array}$} \\
\hline \multirow[t]{2}{*}{ Stable employment } & & & & -0.069 \\
\hline & & & & $(0.089)$ \\
\hline \multirow[t]{2}{*}{ Constant } & $-1.712^{\star \star \star}$ & $-4.244^{\star \star \star}$ & $-4.405^{\star \star \star}$ & $-4.406^{\star \star \star}$ \\
\hline & $(0.059)$ & $(0.098)$ & $(0.107)$ & $(0.186)$ \\
\hline$N$ & 40,462 & 40,462 & 40,462 & 40,462 \\
\hline
\end{tabular}

Note: ${ }^{* *} p<0.01,{ }^{* *} p<0.05,{ }^{*} p<0.1$

Source: Calculations based on $\mathrm{TeO} 2008$

Controlling for partnership formation also affects the first birth rate of children of Maghrebian immigrants, for whom the parameter becomes significant and positive. Their lower gross first birth rate is thus linked to their lower propensity to form a union. Once cultural background is taken into account, the Maghrebian second generation appear to have a significantly lower propensity to have a first child (Model 3). Controlling for socioeconomic variables widens the gap between the Maghrebian second generation and the native French (Model 4).

From these models, it appears that the higher first child rate for Turkish descendants of immigrants is mainly due to cultural background and their higher rates of union formation. Differences with respect to natives disappear when these factors are taken into account. Patterns are very different for the three other groups: they have a lower first birth rate and the difference with respect to natives increases when cultural background or education level is controlled for. Their lower first birth rate is thus not explained by observed cultural factors or their educational level. This is due partly to lower rates of union for these three groups and to the fact they are more often still in education or in nonpermanent employment, and also to unobserved factors. 


\subsection{Second birth}

Overall, the patterns of transition to the second child by origin are similar to those of the transition to first child (Table 4). The first birth occurs earlier for the Turkish second generation, later for the sub-Saharan African second generation, and is very similar for the Maghrebian second generation and French natives. Differences between origins are slightly less marked than for the first child. In particular, although the transition from one to two children is slower for the Southeast Asian second generation with respect to French natives, their median age at second birth is the same.

The transition to the second birth appears to be mainly related to timing (i.e., age at first birth, years since first birth, and having completed education), as well as to cohort, being in a union or having married, and being highly educated (Table 6). Contrary to the first birth, parental background does not affect the risk of a second birth and being in stable employment reduces the probability of having a second child. After controlling for these characteristics, regardless of the set of variables included, there is no significant difference between groups of origin.

The higher probability of having a second child for children of Turkish immigrants compared to French natives, observed in Model 1, is no longer significant after controlling for parental background. Including the background variables step by step (results not shown here, available on request) shows that the higher propensity to have a second child for the second generation from Turkey appears to be related to higher religiosity and foreign language most often spoken during childhood (the coefficient is no longer significant when one of these variables is included).

\section{Table 6: Multilevel discrete-time logistic regression of probability of second} conception

\begin{tabular}{lcccc}
\hline & Model 1 & Model 2 & Model 3 & Model 4 \\
\hline Migration background (ref= Native) & & & & 0.033 \\
2G Maghreb & 0.103 & 0.090 & 0.036 & $(0.099)$ \\
& $(0.075)$ & $(0.084)$ & $(0.098)$ & -0.239 \\
2G Sub-Saharan Africa & -0.160 & -0.149 & $(0.226$ & $(0.183)$ \\
& $(0.151)$ & $(0.165)$ & $-0.178)$ & $(0.203)$ \\
2G Southeast Asia & -0.225 & -0.161 & $(0.200)$ & -0.101 \\
& $(0.198)$ & $(0.193)$ & -0.087 & $(0.191)$ \\
2G Turkey & $0.284^{*}$ & 0.019 & $(0.188)$ & -0.062 \\
Parental background (ref = unmixed) & $(0.163)$ & $(0.173)$ & & $(0.121)$ \\
Descendant of mixed parental background & $-0.238^{\star *}$ & -0.124 & -0.072 & $-0.161^{* *}$ \\
Birth cohort (ref $=$ 1958-1974) & $(0.106)$ & $(0.115)$ & $(0.120)$ & $(0.082)$ \\
Cohort 1975-1990 & & & & -0.130 \\
\end{tabular}


Table 6: (Continued)

\begin{tabular}{|c|c|c|c|c|}
\hline & Model 1 & Model 2 & Model 3 & Model 4 \\
\hline \multicolumn{5}{|c|}{ Years since first birth (ref $=4-6$ ) } \\
\hline \multirow[t]{2}{*}{$0-1$} & $-1.963^{\star \star \star}$ & $-1.893^{* * *}$ & $-1.892^{\star \star \star}$ & $-1.856^{\star * *}$ \\
\hline & $(0.182)$ & $(0.188)$ & $(0.186)$ & $(0.181)$ \\
\hline \multirow[t]{2}{*}{$2-3$} & $-0.872^{\star \star \star}$ & $-0.919^{* * *}$ & $-0.921^{\star \star *}$ & $-0.933^{\star * *}$ \\
\hline & $(0.098)$ & $(0.099)$ & $(0.098)$ & $(0.097)$ \\
\hline \multirow[t]{2}{*}{$7+$} & $-0.515^{\star \star \star}$ & $-0.482^{* * *}$ & $-0.479^{\star \star *}$ & $-0.459^{* * *}$ \\
\hline & $(0.103)$ & $(0.108)$ & $(0.107)$ & $(0.107)$ \\
\hline \multicolumn{5}{|c|}{ Partnership status (ref $=$ single) } \\
\hline \multirow[t]{2}{*}{ Married } & & $0.581^{* \star \star}$ & $0.575^{\star \star \star}$ & $0.561^{\star * *}$ \\
\hline & & $(0.083)$ & $(0.083)$ & $(0.083)$ \\
\hline \multirow[t]{2}{*}{ Cohabiting } & & $0.355^{\star * \star}$ & $0.363^{\text {***}}$ & $0.366^{* * *}$ \\
\hline & & $(0.133)$ & $(0.134)$ & $(0.137)$ \\
\hline \multicolumn{5}{|c|}{$\begin{array}{l}\text { Type of union (ref = no partner or same } \\
\text { origin) }\end{array}$} \\
\hline \multirow[t]{2}{*}{ Mixed union } & & $-0.182^{\star *}$ & $-0.173^{\star \star}$ & $-0.176^{\star \star}$ \\
\hline & & $(0.082)$ & $(0.082)$ & $(0.082)$ \\
\hline \multicolumn{5}{|l|}{ Age at first birth (ref= 25-29) } \\
\hline \multirow[t]{2}{*}{$<25$} & & 0.033 & 0.031 & 0.078 \\
\hline & & $(0.071)$ & $(0.072)$ & $(0.078)$ \\
\hline \multirow[t]{2}{*}{$30-34$} & & $-0.371^{* * *}$ & $-0.371^{\star * *}$ & $-0.424^{\star \star *}$ \\
\hline & & $(0.108)$ & $(0.108)$ & $(0.108)$ \\
\hline \multirow[t]{2}{*}{$35+$} & & $-0.915^{* * *}$ & $-0.926^{\star * *}$ & $-1.008^{* * *}$ \\
\hline & & $(0.234)$ & $(0.234)$ & $(0.238)$ \\
\hline \multicolumn{5}{|l|}{ Sex of first child (ref=boy) } \\
\hline \multirow[t]{2}{*}{ Girl } & & 0.071 & 0.065 & 0.077 \\
\hline & & $(0.064)$ & $(0.064)$ & $(0.065)$ \\
\hline \multicolumn{5}{|c|}{$\begin{array}{l}\text { Importance of religion in own education } \\
\text { (ref= Not or barely) }\end{array}$} \\
\hline \multirow[t]{2}{*}{ Rather or very important } & & & 0.041 & 0.008 \\
\hline & & & $(0.070)$ & $(0.071)$ \\
\hline \multicolumn{5}{|c|}{$\begin{array}{l}\text { Parents' social class (ref= Higher than } \\
\text { unskilled) }\end{array}$} \\
\hline \multirow[t]{2}{*}{ Unskilled blue or white collar } & & & -0.014 & -0.020 \\
\hline & & & $(0.081)$ & $(0.083)$ \\
\hline \multicolumn{5}{|c|}{ Number of siblings (ref= Less than 2) } \\
\hline \multirow[t]{2}{*}{2 or 3} & & & -0.038 & -0.001 \\
\hline & & & $(0.086)$ & $(0.087)$ \\
\hline \multirow[t]{2}{*}{$4+$} & & & 0.001 & 0.053 \\
\hline & & & $(0.096)$ & $(0.099)$ \\
\hline \multicolumn{5}{|c|}{$\begin{array}{l}\text { Language spoken by parents (ref= Only } \\
\text { French / French and foreign) }\end{array}$} \\
\hline Only foreign & & & 0.195 & 0.198 \\
\hline & & & $(0.131)$ & $(0.134)$ \\
\hline Educational level (ref= No q & & & & \\
\hline Lower vocational & & & & 0.071 \\
\hline & & & & $(0.091)$ \\
\hline Secondary & & & & 0.001 \\
\hline & & & & $(0.100)$ \\
\hline Higher & & & & $0.366^{* * *}$ \\
\hline & & & & $(0.105)$ \\
\hline
\end{tabular}


Pailhé: The convergence of second-generation immigrants' fertility patterns in France

Table 6: (Continued)

\begin{tabular}{|c|c|c|c|c|}
\hline & Model 1 & Model 2 & Model 3 & Model 4 \\
\hline \multicolumn{5}{|c|}{ Education status (ref=in education) } \\
\hline \multirow[t]{2}{*}{ No longer in education } & & & & $1.078^{\star \star \star}$ \\
\hline & & & & $(0.299)$ \\
\hline \multicolumn{5}{|c|}{$\begin{array}{l}\text { Labour market status (ref.= Not in stable } \\
\text { employment) }\end{array}$} \\
\hline \multirow[t]{2}{*}{ Stable employment } & & & & $-0.250^{\star \star *}$ \\
\hline & & & & $(0.095)$ \\
\hline \multirow[t]{2}{*}{ Constant } & $-1.120^{\star \star \star}$ & $-1.732^{* * *}$ & $-1.730^{* * *}$ & $-2.723^{\star * *}$ \\
\hline & $(0.060)$ & $(0.147)$ & $(0.157)$ & $(0.336)$ \\
\hline $\mathrm{N}$ & 9,492 & 8,835 & 8,835 & 8,835 \\
\hline
\end{tabular}

Sample: Women with at least one child, no multiple births at first childbirth

Note: ${ }^{* \star *} p<0.01,{ }^{* \star} p<0.05,{ }^{*} p<0.1$

Source: Calculations based on $\mathrm{TeO} 2008$

\subsection{Third birth}

Among parents of two children, the share of those who have three children at age 40 is much higher for the second generation from the Maghreb: 61\% compared to about 38\% for the native French.

This gap between women of Maghrebian descent and French natives still holds when taking into account cohort, marital status, age at first birth, sex of the two firstborn children, and educational level (Table 7). However, it disappears when background variables are considered. The coefficient for descendants of immigrants from the Maghreb is no longer significant when the number of siblings is controlled for. Including step by step the other background variables does not have such an effect (results not shown here, available on request). Thus, the higher propensity to have a third child for the second generation from the Maghreb appears to be related to the parents' family structure, and thus to a transmission of the parents' fertility patterns.

\section{Table 7: Multilevel discrete-time logistic regression of probability of third conception}

\begin{tabular}{lcccc}
\hline & Model 1 & Model 2 & Model 3 & Model 4 \\
\hline Migration background (ref= Native) & & & & \\
2G Maghreb & $0.618^{\star \star \star}$ & $0.543^{\star \star \star}$ & 0.048 & 0.040 \\
& $(0.151)$ & $(0.167)$ & $(0.172)$ & $(0.165)$ \\
Parental background (ref = unmixed) & & & & $0.357^{\star}$ \\
Descendant of mixed parental background & -0.018 & -0.038 & $(0.211)$ & $(0.208)$ \\
\hline
\end{tabular}


Table 7: (Continued)

\begin{tabular}{|c|c|c|c|c|}
\hline & Model 1 & Model 2 & Model 3 & Model 4 \\
\hline \multicolumn{5}{|l|}{ Birth cohort (ref = 1958-1974) } \\
\hline \multirow[t]{2}{*}{ Cohort 1975-1990 } & 0.157 & -0.026 & -0.041 & -0.041 \\
\hline & $(0.169)$ & $(0.179)$ & $(0.171)$ & $(0.169)$ \\
\hline \multicolumn{5}{|l|}{ Years since first birth (ref $=2-5$ ) } \\
\hline \multirow[t]{2}{*}{$0-1$} & $-0.778^{* \star *}$ & $-0.789^{* \star *}$ & $-0.722^{\star * *}$ & $-0.703^{\text {** }}$ \\
\hline & $(0.221)$ & $(0.240)$ & $(0.226)$ & $(0.202)$ \\
\hline \multirow[t]{2}{*}{$6+$} & $-1.055^{\star \star \star}$ & $-1.089^{* \star \star}$ & $-1.156^{\star \star \star}$ & $-1.165^{\star \star \star}$ \\
\hline & $(0.217)$ & $(0.228)$ & $(0.223)$ & $(0.212)$ \\
\hline \multicolumn{5}{|l|}{ Partnership status (ref = single) } \\
\hline \multirow[t]{2}{*}{ Married } & & $0.748^{* * *}$ & $0.703^{* * *}$ & $0.677^{* \star \star}$ \\
\hline & & $(0.210)$ & $(0.201)$ & $(0.192)$ \\
\hline \multirow[t]{2}{*}{ Cohabiting } & & -0.162 & -0.176 & -0.050 \\
\hline & & $(0.294)$ & $(0.277)$ & $(0.271)$ \\
\hline \multicolumn{5}{|l|}{$\begin{array}{l}\text { Type of union (ref = no partner or same } \\
\text { origin) }\end{array}$} \\
\hline \multirow[t]{2}{*}{ Mixed union } & & 0.158 & 0.164 & 0.136 \\
\hline & & $(0.168)$ & $(0.154)$ & $(0.147)$ \\
\hline \multicolumn{5}{|l|}{ Age at first birth (ref= 25-29) } \\
\hline \multirow[t]{2}{*}{$<25$} & & $0.673^{* * *}$ & $0.606^{* * *}$ & $0.599^{\star \star \star}$ \\
\hline & & $(0.148)$ & $(0.137)$ & $(0.141)$ \\
\hline \multirow[t]{2}{*}{$30-34$} & & -0.338 & -0.272 & -0.297 \\
\hline & & $(0.259)$ & $(0.246)$ & $(0.241)$ \\
\hline \multirow[t]{2}{*}{$35+$} & & 0.119 & 0.004 & 0.054 \\
\hline & & $(0.535)$ & $(0.507)$ & $(0.494)$ \\
\hline \multicolumn{5}{|l|}{$\begin{array}{l}\text { Sex of the two first-born children (ref=boy } \\
\text { and girl) }\end{array}$} \\
\hline \multirow[t]{2}{*}{ Same sex } & & $0.281^{\star *}$ & $0.268^{* *}$ & $0.253^{* *}$ \\
\hline & & $(0.131)$ & $(0.125)$ & $(0.119)$ \\
\hline \multicolumn{5}{|c|}{$\begin{array}{l}\text { Importance of religion in own education (ref= } \\
\text { Not or barely) }\end{array}$} \\
\hline \multirow[t]{2}{*}{ Rather or very important } & & & $0.237^{*}$ & 0.186 \\
\hline & & & $(0.126)$ & $(0.123)$ \\
\hline \multicolumn{5}{|l|}{$\begin{array}{l}\text { Parents' social class (ref= Higher than } \\
\text { unskilled) }\end{array}$} \\
\hline \multirow[t]{2}{*}{ Unskilled blue or white collar } & & & -0.185 & -0.186 \\
\hline & & & $(0.147)$ & $(0.144)$ \\
\hline \multicolumn{3}{|l|}{ Number of siblings (ref= Less than 2 ) } & 0.000 & 0.000 \\
\hline \multirow[t]{2}{*}{2 or 3} & & & 0.155 & 0.187 \\
\hline & & & $(0.175)$ & $(0.169)$ \\
\hline \multirow[t]{2}{*}{$4+$} & & & $0.641^{\text {***}}$ & $0.672^{* \star \star}$ \\
\hline & & & $(0.194)$ & $(0.191)$ \\
\hline \multicolumn{5}{|l|}{$\begin{array}{l}\text { Language spoken by parents (ref= Only } \\
\text { French / French and foreign) }\end{array}$} \\
\hline \multirow[t]{2}{*}{ Only foreign } & & & $0.823^{\star \star *}$ & $0.731^{* * \star}$ \\
\hline & & & $(0.228)$ & $(0.220)$ \\
\hline
\end{tabular}


Table 7: (Continued)

\begin{tabular}{|c|c|c|c|c|}
\hline & Model 1 & Model 2 & Model 3 & Model 4 \\
\hline \multicolumn{5}{|c|}{ Educational level (ref= No qualifications) } \\
\hline \multirow[t]{2}{*}{ Lower vocational } & & & & -0.165 \\
\hline & & & & $(0.152)$ \\
\hline \multirow[t]{2}{*}{ Secondary } & & & & -0.092 \\
\hline & & & & $(0.191)$ \\
\hline \multirow[t]{2}{*}{ Higher } & & & & 0.273 \\
\hline & & & & $(0.179)$ \\
\hline \multicolumn{5}{|c|}{ Education status (ref=in education) } \\
\hline \multirow[t]{2}{*}{ No longer in education } & & & & 0.843 \\
\hline & & & & $(1.080)$ \\
\hline \multicolumn{5}{|c|}{$\begin{array}{l}\text { Labour market status (ref.= Not in stable } \\
\text { employment) }\end{array}$} \\
\hline \multirow[t]{2}{*}{ Stable employment } & & & & $-0.518^{* * \star}$ \\
\hline & & & & $(0.172)$ \\
\hline \multirow[t]{2}{*}{ Constant } & $-2.674^{\star \star \star}$ & $-3.548^{\star \star \star}$ & $-3.723^{\star \star \star}$ & $-4.173^{\star \star \star}$ \\
\hline & $(0.120)$ & $(0.388)$ & $(0.394)$ & $(1.167)$ \\
\hline$N$ & 7,878 & 7,878 & 7,878 & 7,878 \\
\hline
\end{tabular}

Sample: Women with at least two children, no multiple births at first two childbirths

Note: ${ }^{* * *} p<0.01,{ }^{* *} p<0.05,{ }^{*} p<0.1$

Source: Calculations based on $\mathrm{TeO} 2008$

\subsection{Effect of culture and educational level by origin}

The effect of religiosity differs slightly across groups of origin (Figure A-1 in Appendix). However, the differences remain nonsignificant. In line with our hypothesis $\mathrm{H} 2 \mathrm{a}$, nonreligious descendants of immigrants from the Maghreb have birth risks comparable to those of French natives, whatever the birth order. Conversely, religious women from the Maghreb tend to have higher second and third birth risks than religious native women (differences are not significant, however). In the other groups of origin, nonreligious women tend to have lower birth risks than comparable French natives. Religiosity tends to have a stronger positive effect on the fertility of children of immigrants from Muslim countries, which is consistent with our hypothesis H2b. However, for the first birth it is observed only for descendants of Turkish immigrants and for higher birth orders for descendants of Maghrebian immigrants, and the differences are not significant.

Intergenerational transmission of fertility behaviours is observed: fertility risks are higher among those from large families, with significant differences across origins (Figure A-2 in Appendix). Among descendants of immigrants from sub-Saharan Africa and Southeast Asia, first birth risks depend strongly on the number of siblings. In these groups of origin, women with fewer than two siblings have lower first birth risks than 
comparable natives, and those who were raised in large families tend to have lower second birth risks than natives and Turkish descendants of immigrants (differences are nonsignificant). Descendants of immigrants from the Maghreb raised in large families have the same birth risks as comparable French natives, whatever the birth order. Our hypothesis $\mathrm{H} 2 \mathrm{c}$ is partially validated: the intergenerational transmission of fertility behaviour appears to be lower among descendants of immigrants from Southeast Asia, but it is not higher among descendants from the Maghreb or sub-Saharan Africa.

Birth risks are strongly dependent on educational level (Figure A-2 in Appendix). Whatever the origin, first birth risks are higher among the less-educated. First birth risks converge across groups of origin for women with a tertiary level of education. They are even lower among highly educated women from the Maghreb and Southeast Asia compared to highly educated French natives. Second birth risks tend to be higher among the more highly educated for all groups except daughters of immigrants from Turkey, but this difference is significant among French natives only. Third birth risks are also higher for French natives with tertiary education, and differences across levels of education are also more marked for them than for descendants of Maghrebian immigrants, for whom third birth risks do not depend on educational level. Thus, we observe that access to higher levels of education erases differences between groups for first birth risks and tends to reduce fertility compared to French natives for higher birth orders.

\section{Conclusion and discussion}

This study analysed the transition to first, second, and third births for four groups of female second-generation immigrants in France, i.e., from the Maghreb, sub-Saharan Africa, Turkey, and Southeast Asia. Using rich data from the Trajectories and Origin survey and comparing descendants of immigrants to the native French, it looked for evidence of a convergence in fertility patterns and examined how the specific background of immigrants' descendants shapes childbearing patterns. In order to assess the effect of socialization vs. assimilation we analysed the effects of parental background and educational attainment.

We find that childbearing patterns differ by origin. As expected, women of Southeast Asian descent have lower fertility and postpone childbearing compared to the other daughters of immigrants. They even enter childbearing much later and have lower first birth rates than native French women. They do not show significant differences in timing and rates of second births. Their lower propensity to have a first child is related to their lower propensity to form a union. Their higher educational level also contributes to this lower fertility, and even to a deviation from the French pattern. 
Hence, daughters of immigrants from Southeast Asia with a tertiary level of education are less likely to have a first and second child than French natives with the same educational level. Previous research has shown that children of immigrants from Southeast Asia perform better at school than other groups (Brinbaum, Mauguérou, and Primon 2015), due to their parents' high educational aspirations (Ichou and Oberti 2014). Their strong ambition to integrate through education and employment seems to increase the opportunity cost of children for them, which reduces fertility. The delayed and reduced fertility is partly inherited from their parents. Hence, Pailhé and Hamel (2015) have shown that among immigrants, those of Asian origin are among the most similar to the native French in terms of the age at first childbearing. However, their children deviate from the fertility pattern of their parents insofar as they have their first child later than the native French, and even those from large or religious families have lower fertility.

By contrast, Turkish descendants of immigrants enter motherhood at younger ages and have higher first and second birth rates compared to the native French. This early childbearing is linked to their young age at partnership formation, their cultural background, and, to a lesser extent, to their lower human capital. Indeed, once these compositional effects are taken into account there is no significant difference when compared to the native French. This result is in line with that of Milewski (2010) for Germany. We show that the background variables most significant for this group are religiosity and the language spoken at home. Women who only speak Turkish at home, and thus who are less assimilated, have a higher risk of a first and second child. Religiosity also tends to have a greater effect for this group than for the others. This is the group that most strongly preserves their parents' cultural heritage. Due to the younger age structure we were not able to analyse third birth rates for this group, but given their earlier and higher fertility we can expect them to also display higher third birth rates (see Kulu et al. 2017).

The two groups of African descent are quite close in terms of characteristics, but adopt different fertility patterns. Descendants of sub-Saharan immigrants tend to postpone both first and second births, partly because they form their first union later but also because they adopt the French model of late childbearing and small family size. Notably, even those who come from large families have lower fertility. They appear to adapt to the society of settlement - especially the most educated, who have lower fertility than comparable French natives. Afulani and Asunka (2015) have shown that some of them may be forced to reduce their fertility and are unable to reach their high fertility ideals. However, this group is still young, and further research is needed to analyse more fully the transition to second and subsequent births.

Regarding transition to the first and second child, it is the descendants of Maghrebian immigrants who exhibit the greatest convergence with the French fertility 
pattern. Pailhé and Hamel (2015) have shown that their completed fertility remains close to that of native French women, with 1.9 and 1.8 children per women on average at age 40 respectively, but with a larger share of families with 3 children and more, 39\% and $26 \%$ respectively. We show here that fertility behaviours are especially polarized among this group: A significant proportion have a child late $(22 \%$ have their first child after 30 ) or remain childless (17\%), while a large proportion of mothers of two children go on to have a third $(61 \%)$. The lower first birth rates are a consequence of their lower propensity to form a union. The most educated women also have much lower rates of first union. Even the more religious and those from large families have lower first birth risks than the comparable native French: However, they have a higher propensity to have a third child. Women from a large or religious family adapt in terms of tempo, but less so in terms of quantum.

Thus, in line with our first hypothesis, fertility patterns differ across groups of origin. As expected, women whose parents come from the country that is culturally distant - Turkey - have their first child earlier and have higher first and second birth rates. But $\mathrm{H} 1$ is validated for this group only. Those of the second generation from Southeast Asia have delayed and lower fertility compared to the other groups of daughters of immigrants. Contrary to our expectations (H1c), the second generations from Southeast Asia and sub-Saharan Africa have their first child later, and the timing of childbearing among descendants of immigrants from the Maghreb converges towards French norms. This (over-)convergence is not an exact reflection of the sociocultural distance between source and destination country.

Our hypothesis $\mathrm{H} 1 \mathrm{~b}$ was that convergence occurs differently according to birth order. There is clearly no difference for the transition to the second child. This confirms that the strong norm regarding the timing of transition to the second birth is also endorsed by second-generation immigrants. By contrast, differences are huge regarding the transition to the third child. It seems that, for the groups for whom we were able to analyse the transition to third birth, there is both an adaptation of the timing of the first and second births and a transmission of the parents' family-oriented values regarding higher birth orders.

There are various mechanisms by which this convergence occurs. First, women with numerous siblings have higher birth rates. Thus, intergenerational continuities in fertility behaviour are observed via the transmission of a preference for large families $(\mathrm{H} 2 \mathrm{c})$. However, this transmission is less marked among descendants of immigrants from the Maghreb and Southeast Asia. Language spoken during childhood also affects the first and third birth rates. Women who speak only a foreign language have their first child at a younger age. Speaking only a foreign language indicates lower integration into the host society, and thus a lower adaptation to French standards. This is particularly common for women of Turkish origin. Among cultural factors, religious 
belief has a different effect on birth rate, depending on group and birth order. Religiosity has a stronger positive effect on the fertility of children of immigrants from Turkey for the first birth and for descendants of Maghrebian immigrants for higher birth orders. Other studies have shown that religiosity strongly affects partnership formation patterns (Pailhé 2015), and thus is indirectly linked to fertility.

Second, the various patterns of adaptation depend on access to a higher level of education. In line with our third hypothesis, education is a crucial factor that erases differences between groups. Highly educated women distance themselves from parental norms; they also enter the workforce at higher ages as a result of prolonged enrolment in education, and this reduces childbearing. Hence, due to rising opportunity costs, they prioritize employment over childbearing in order to ensure a return on their investment in education. First birth risks converge across groups of origin for women with a tertiary level of education, but differ among the less-educated. This effect appears to be particularly strong for groups that invest the most in education.

Finally, both structural and cultural factors explain the cross-group differences in the timing of fertility, with the relative influence of such factors varying across groups of descendants of immigrants. For descendants of immigrants in France, cultural factors have much less influence on the timing of entry into adulthood than on union formation. These cultural factors might have a much stronger effect on completed fertility than on the timing of first births; further research is needed to analyse completed fertility. In particular, a comparison of completed fertility and fertility ideals would reveal whether the postponement of childbearing results in fewer children than intended, thus reflecting specific constraints weighing upon the descendants of immigrants. In France, most groups of descendants of immigrants are still too young for such an analysis.

\section{Acknowledgments}

I am grateful for comments and suggestions from Hill Kulu, Tina Hannemann, and two anonymous reviewers. The research leading to these results received funding from the European Union's Seventh Framework Programme (FP7/2007-2013), under grant agreement no. 320116 for the research project FamiliesAndSocieties. 


\section{References}

Adserà, A. and Ferrer, A. (2014). Immigrants and demography: Marriage, divorce, and fertility. Bonn: Forschungsinstitut zur Zukunft und Arbeit (Discussion Paper No. 7982).

Afulani, P.A. and Asunka, J. (2015). Socialization, adaptation, transnationalism, and the reproductive behavior of sub-Saharan African migrants in France. Population Research and Policy Review 34(4): 561-592. doi:10.1007/s11113-015-9360-2.

Alba, R. (2005). Bright vs. blurred boundaries: Second-generation assimilation and exclusion in France, Germany, and the United States. Ethnic and Racial Studies 28(1): 20-49. doi:10.1080/0141987042000280003.

Alba, R. and Nee, V. (2003). Remaking the American mainstream: Assimilation and contemporary immigration. Cambridge: Harvard University Press. doi:10.4159/ 9780674020115 .

Algava, E. and Lhommeau, B. (2015). Echantillonnage, collecte et pondération de l'enquête trajectoires et origines. In: Beauchemin, C., Hamel, C., and Simon, P. (eds.). Trajectoires et origines - Enquête sur la diversité des populations en France (collection Grandes enquêtes). Paris: Institut national d'études démographiques: 585-616.

Allison, P.D. (1982). Discrete-time methods for the analysis of event histories. Sociological Methodology 13: 61-98. doi:10.2307/270718.

Barber, J.S. (2001). The intergenerational transmission of age at first birth among married and unmarried men and women. Social Science Research 30(2): 219247. doi:10.1006/ssre.2000.0697.

Beauchemin, C., Hamel, C., and Simon, P. (2010). Trajectories and origins: Survey on population diversity in France. Paris: Institut national d'études démographiques (Documents de travail 168).

Becker, G.S. (1981). A treatise on the family. Cambridge: Harvard University Press.

Brinbaum, Y., Mauguérou, L., and Primon, J.L. (2015). Les trajectoires du primaire au supérieur des descendants d'immigrés et de natifs des DOM. In: Beauchemin, C., Hamel, C., and Simon, P. (eds.). Trajectoires et origines - Enquête sur la diversité des populations en France (collection Grandes enquêtes). Paris: Institut national d'études démographiques: 175-202. 
Brinbaum, Y., Meurs, D., and Primon, J.L. (2015). Situation sur le marché du travail: Statuts d'activités, accès à l'emploi et discrimination. In: Beauchemin, C., Hamel, C., and Simon, P. (eds.). Trajectoires et origines - Enquête sur la diversité des populations en France (collection Grandes enquêtes). Paris: Institut national d'études démographiques: 203-232.

Chabé-Ferret, B. and Melindi-Ghidi, P. (2013). Differences in fertility behavior and uncertainty: An economic theory of the minority status hypothesis. Journal of Population Economics 26(3): 887-905. doi:10.1007/s00148-012-0434-8.

Ciganda, D. (2015). Unstable work histories and fertility in France: An adaptation of sequence complexity measures to employment trajectories. Demographic Research 32(28): 843-876. doi:10.4054/DemRes.2015.32.28.

Collet, B. and Santelli, E. (2012). Couples d'ici, parents d'ailleurs: Parcours de descendants d'immigrés. Paris: Presses universitaires de France.

Crul, M., Schneider, J., and Lelie, F. (2012). The European second generation compared: Does the integration context matter? Amsterdam: Amsterdam University Press.

De Valk, H.A.G. and Liefbroer, A. (2007). Timing preferences for women's family life transitions: Intergenerational transmission among migrants and Dutch. Journal of Marriage and Family 69(1): 190-207. doi:10.1111/j.1741-3737.2006.003 53.x.

De Valk, H.A.G. and Milewski, N. (2011). Family life transitions among children of immigrants: An introduction. Advances in Life Course Research 16(4): 145-151. doi:10.1016/j.alcr.2011.10.001.

Dubuc, S. (2012). Immigration to the UK from high-fertility countries: Intergenerational adaptation and fertility convergence. Population and Development Review 38(2): 353-368. doi:10.1111/j.1728-4457.2012.00496.x.

Ferrari, G. and Pailhé, A. (2017). Transition to adulthood in France: Do children of immigrants differ from natives? Advances in Life Course Research 31(1): 34-56. doi:10.1016/j.alcr.2016.10.001.

Furtado, D. (2012). Human capital and interethnic marriage decisions. Economic Inquiry 50(1): 82-93. doi:10.1111/j.1465-7295.2010.00345.x.

Garssen, J. and Nicholaas, H. (2008). Fertility of Turkish and Moroccan women in the Netherlands: Adjustment to native level within one generation. Demographic Research 19(33): 1249-1280. doi:10.4054/DemRes.2008.19.33. 
Goldscheider, C. and Uhlenberg, P.R. (1969). Minority group status and fertility. American Journal of Sociology 74(4): 361-372. doi:10.1086/224662.

Gordon, M. (1964). Assimilation in American life: The role of race, religion and national origins. New York: Oxford University Press.

Halli, S.S. (1989). Toward a re-conceptualization of minority group status and fertility hypothesis: The case of Orientals in Canada. Journal of Comparative Family Studies 20(1): 21-46.

Hank, K. and Kohler, H.P. (2003). Sex preferences for children revisited: New evidence from Germany. Population 58(1): 133-143. doi:10.3917/pope.301.0133.

Héran, F. and Pison, G. (2007). Two children per woman in France in 2006: Are immigrants to blame? Population and Societies 432.

Hervitz, H.M. (1985). Selectivity, adaptation, or disruption? A comparison of alternative hypotheses on the effects of migration on fertility: The case of Brazil. International Migration Review 19(2): 293-317. doi:10.2307/2545774.

Huschek, D., Liefbroer, A., and de Valk, H.A.G. (2010). Timing of first union among second-generation Turks in Europe: The role of parents, peers and institutional context. Demographic Research 22(16): 473-504. doi:10.4054/DemRes. 2010.22.16.

Ichou, M. and Oberti, M. (2014). Immigrant families' relationship with the school system: A survey of four working-class suburban high schools. Population 69(4): 557-597.

Inglehart, R. and Welzel, C. (2005). Modernization, cultural change and democracy. New York: Cambridge University Press. doi:10.1017/CBO9780511790881.

INSEE (2012). Immigrés et descendants d'immigrés en France. Paris: INSEE.

Kulu, H. (2005). Migration and fertility: Competing hypotheses re-examined. European Journal of Population 21: 51-87. doi:10.1007/s10680-005-3581-8.

Kulu, H. and Hannemann, T. (2016). Why does fertility remain high among certain UKborn ethnic minority women? Demographic Research 35(49): 1441-1488. doi:10.4054/DemRes.2016.35.49.

Kulu, H., Hannemann T., Pailhé, A., Neels, K., Krapf, S., Gonzàles-Ferrer, A., and Andersson, G. (2017). Fertility by birth order among the descendants of immigrants in selected European countries. Population and Development Review 43(1): 31-60. doi:10.1111/padr.12037. 
Pailhé: The convergence of second-generation immigrants' fertility patterns in France

Lee, R. (2013). Intergenerational transfers, the biological life cycle, and human society. Population and Development Review 38(S1): 23-35. doi:10.1111/j.1728-4457. 2013.00549.x.

Meurs, D., Pailhé, A., and Simon, P. (2006). The persistence of intergenerational inequalities linked to immigration: Labour market outcomes for immigrants and their descendants in France. Population 61(5-6): 763-801. doi:10.3917/popu.60 5.0763 .

Michaël, R.T. and Tuma, N.B. (1985). Entry into marriage and parenthood by young men and women: The influence of family background. Demography 22(4): 515544. doi:10.2307/2061586.

Milewski, N. (2007). First child of immigrant workers and their descendants in West Germany: Interrelation of events, disruption, or adaptation? Demographic Research 17(29): 859-896. doi:10.4054/DemRes.2007.17.29.

Milewski, N. (2010). Fertility of immigrants: A two-generational approach in Germany. Heidelberg: Springer. doi:10.1007/978-3-642-03705-4.

Milewski, N. (2011). Transition to a first birth among Turkish second-generation migrants in Western Europe. Advances in Life Course Research 16(4): 178-189.

Mills, M., Blossfeld, H.P., and Klijzing, E. (2005). Becoming an adult in uncertain times: A 14-country comparison of the losers of globalization. In: Blossfeld, H.-P., Klijzing, E., Mills, M., and Kurz, K. (eds.). Globalization, uncertainty and youth in society. London: Routledge: 423-441.

Ní Bhrolcháin, M. and Beaujouan, É. (2012). Fertility postponement is largely due to rising educational enrolment. Population Studies 66(3): 311-327. doi:10.1080/ 00324728.2012.697569.

Pailhé, A. (2015). Partnership dynamics across generations of immigration in France: Structural vs. cultural factors. Demographic Research 33(16): 451-498. doi:10.4054/DemRes.2015.33.16.

Pailhé, A. and Hamel, C. (2015). Avoir des enfants en contexte migratoire. In: Beauchemin, C., Hamel, C., and Simon, P. (eds.). Trajectoires et origines Enquête sur la diversité des populations en France (collection Grandes enquêtes). Paris: Institut national d'études démographiques: 323-352.

Pailhé, A. and Solaz, A. (2012). The influence of employment uncertainty on childbearing in France: A tempo or quantum effect? Demographic Research 26(1): 1-40. doi:10.4054/DemRes.2012.26.1. 
Pailhé, A. and Solaz, A. (2013). Employment instability and childbearing plans in a child-oriented country. Evidence from France. In: Olah, L. and Fratczak, E. (eds.). Childbearing, women's employment and work-life balance policies in contemporary Europe. Basingstoke: Palgrave Macmillan: 65-96. doi:10.1057/ 97811373185413.

Pla, A. and Beaumel, C. (2012). Bilan démographique 2011: La fécondité reste élevée. Paris: INSEE (INSEE Première $n^{\circ} 1385$ ).

Portes, A., Fernandez-Kelly, P., and Haller, W. (2009). Segmented assimilation on the ground: The new second generation in early adulthood. Ethnic and Racial Studies 28(6): 1000-1040. doi:10.1080/01419870500224117.

Portes, A. and Zhou, M. (1993). The new second generation: Segmented assimilation and its variants. Annals of the American Academy of Political and Social Science 530: 74-96. doi:10.1177/0002716293530001006.

Prioux, F. (2003). Age at first union in France: A two-stage process of change. Population 58(4): 559-578. doi:10.3917/pope.304.0559.

Régnier-Loilier, A. (2006). Influence of own sibship size on the number of children desired at various times of life: The case of France. Population 61(3): 165-194. doi:10.3917/pope.603.0165.

Régnier-Loilier, A. and Prioux, F. (2008). Does religious practice influence family behaviours? Population and Societies 447.

Revillard, A. (2006). Work/family policy in France: From state familialism to state feminism? International Journal of Law Policy and the Family 20(2): 133-150. doi:10.1093/lawfam/ebl009.

Rijken, A.J. and Liefbroer, A. (2009). Influences of the family of origin on the timing and quantum of fertility in the Netherlands. Population Studies 63(1): 71-85. doi:10.1080/00324720802621575.

Scott, K. and Stanfors, M. (2011). The transition to parenthood among the second generation: Evidence from Sweden, 1990-2005. Advances in Life Course Research 16(4): 190-204. doi:10.1016/j.alcr.2011.09.003.

Sobotka, T. (2008). The rising importance of migrants for childbearing in Europe. Demographic Research, Special Collection 7: Childbearing Trends and Policies in Europe 19(9): 225-248. doi:10.4054/DemRes.2008.19.9. 
Steenhof, L. and Liefbroer, A. (2008). Intergenerational transmission of age at first birth in the Netherlands for birth cohorts born between 1935 and 1984: Evidence from municipal registers. Population Studies 62(1): 69-84. doi:10.1080/ 00324720701788616.

Toulemon, L. (2004). Fertility among immigrant women: New data, new approach. Population and Societies 400.

Toulemon, L., Pailhé, A., and Rossier, C. (2008). France: High and stable fertility. Demographic Research, Special Collection 7: Childbearing Trends and Policies in Europe 19(16): 503-556. doi:10.4054/DemRes.2008.19.16.

Tribalat, M. (2005). Fécondité des immigrées et apport démographique de l'immigration étrangère. In: Bergouignan, C., Blayo, C., Parant, A., Sardon, J.P., and Tribalat, M. (eds.). La population de la France. Évolutions démographiques depuis 1946. Pessac: CUDEP: 727-767.

Wood, J., Neels, K., and Kil, T. (2014). The educational gradient of childlessness and cohort parity progression in 14 low fertility countries. Demographic Research 31(46): 1365-1416. doi:10.4054/DemRes.2014.31.46. 


\section{Appendix}

Table A-1: Median age at marriage and first birth and TFR in country of origin

\begin{tabular}{lccccc}
\hline & Year & Median age at marriage & Year & Mean age at first birth & TFR 1985-1990 \\
\hline The Maghreb & & & & & \\
Algeria & 1987 & 23.7 & 1992 & 24.9 & 5.3 \\
Morocco & 1982 & 22.2 & 1987 & 22.4 & 4.4 \\
Tunisia & 1984 & 24.3 & 1988 & 24.5 & 4.1 \\
Turkey & 1990 & 22 & 1993 & 21.8 & 3.3 \\
South-East Asia & & & & 6 \\
Cambodia & 1998 & 22.5 & & & \\
Vietnam & 1989 & 23.1 & 1997 & & \\
Sub-Saharan Africa & & & & \\
Senegal & 1993 & 21.6 & 1993 & 19.3 & \\
Mali & 1987 & 18.9 & 1987 & 18.6 & 7.9 \\
Guinea & 1990 & 29 & 1999 & 19.0 & 6.9 \\
Cameroon & 1998 & 20.2 & 1998 & 19.5 & 6.1 \\
Ivory Coast & 1999 & 21.9 & 1999 & & 6.6 \\
\hline
\end{tabular}

Note: Selected years correspond as far as possible to the median year at migration for each origin. For sub-Saharan Africa, main countries of origin are selected.

Source: United Nations, Department of Economic and Social Affairs, Population Division. World Marriage Data 2008; World Population Prospects: The 2010 Revision and World Fertility Report 2012 
Pailhé: The convergence of second-generation immigrants' fertility patterns in France

Table A-2: Sample characteristics

\begin{tabular}{|c|c|c|c|c|c|c|c|c|c|c|}
\hline \multirow[b]{2}{*}{ Mean age } & \multicolumn{2}{|c|}{ 2G Maghreb } & \multicolumn{2}{|c|}{$\begin{array}{c}\text { 2G sub- } \\
\text { Saharan Africa }\end{array}$} & \multicolumn{2}{|c|}{$\begin{array}{l}\text { 2G Southeast } \\
\text { Asia }\end{array}$} & \multicolumn{2}{|c|}{ 2G Turkey } & \multicolumn{2}{|c|}{ Native } \\
\hline & 30.6 & & 24.9 & & 25.2 & & 23.9 & & 35.1 & \\
\hline & $\mathrm{N}$ & $\%$ & $\mathrm{~N}$ & $\%$ & $\mathrm{~N}$ & $\%$ & $\mathrm{~N}$ & $\%$ & $\mathrm{~N}$ & $\%$ \\
\hline $\begin{array}{l}\text { Descendant of mixed } \\
\text { parental background }\end{array}$ & 385 & 28.4 & 114 & 25.7 & 101 & 37.0 & 10 & 4.3 & 0 & 0.0 \\
\hline Cohort 1958-1974 & 466 & 34.3 & 53 & 12.0 & 24 & 8.8 & 9 & 3.9 & 967 & 58.3 \\
\hline Cohort 1975-1990 & 891 & 65.7 & 390 & 88.0 & 249 & 91.2 & 225 & 96.2 & 691 & 41.7 \\
\hline $\begin{array}{l}\text { Unskilled blue or white } \\
\text { collar parents }\end{array}$ & 470 & 34.6 & 147 & 33.2 & 56 & 20.5 & 80 & 34.2 & 203 & 12.2 \\
\hline $\begin{array}{l}\text { Religion rather or very } \\
\text { important }\end{array}$ & 843 & 62.1 & 287 & 64.8 & 109 & 39.9 & 162 & 69.2 & 479 & 28.9 \\
\hline Less than 2 siblings & 118 & 8.7 & 45 & 10.2 & 70 & 25.6 & 24 & 10.3 & 664 & 40.1 \\
\hline 2 or 3 siblings & 431 & 31.8 & 135 & 30.5 & 121 & 44.3 & 103 & 44.0 & 681 & 41.1 \\
\hline 4+ siblings & 808 & 59.5 & 263 & 59.4 & 82 & 30.0 & 107 & 45.7 & 313 & 18.9 \\
\hline Only French spoken & 415 & 30.6 & 175 & 39.5 & 77 & 28.2 & 12 & 5.1 & 1398 & 84.3 \\
\hline $\begin{array}{l}\text { French and foreign language } \\
\text { spoken }\end{array}$ & 787 & 58.0 & 212 & 47.9 & 140 & 51.3 & 109 & 46.6 & 244 & 14.7 \\
\hline Only foreign language spoken & 155 & 11.4 & 56 & 12.6 & 56 & 20.5 & 113 & 48.3 & 16 & 1.0 \\
\hline No qualifications & 312 & 23.0 & 98 & 22.1 & 29 & 10.6 & 89 & 38.0 & 275 & 16.6 \\
\hline Lower vocational education & 279 & 20.6 & 76 & 17.2 & 27 & 9.9 & 53 & 22.7 & 369 & 22.3 \\
\hline Secondary education & 390 & 28.7 & 143 & 32.3 & 104 & 38.1 & 56 & 23.9 & 399 & 24.1 \\
\hline Higher education & 376 & 27.7 & 126 & 28.4 & 113 & 41.4 & 36 & 15.4 & 615 & 37.1 \\
\hline \multicolumn{11}{|l|}{ Women aged 25+ } \\
\hline No qualifications & 227 & 25.1 & 30 & 15.5 & 11 & 9.2 & 34 & 36.6 & 229 & 17.1 \\
\hline Lower vocational education & 202 & 22.4 & 31 & 16.1 & 14 & 11.8 & 20 & 21.5 & 308 & 23.0 \\
\hline Secondary education & 193 & 21.4 & 44 & 22.8 & 15 & 12.6 & 19 & 20.4 & 268 & 20.0 \\
\hline Higher education & 227 & 25.1 & 30 & 15.5 & 11 & 9.2 & 34 & 36.6 & 229 & 17.1 \\
\hline
\end{tabular}

Source: Calculations based on $\mathrm{TeO} 2008$ 
Table A-3: Person-year

\begin{tabular}{|c|c|c|c|c|c|}
\hline & 2G Maghreb & $\begin{array}{c}\text { 2G sub- } \\
\text { Saharan Africa }\end{array}$ & $\begin{array}{l}\text { Southeast } \\
\text { Asia }\end{array}$ & 2G Turkey & Natives \\
\hline $\begin{array}{l}\text { Descendant of mixed } \\
\text { parental background }\end{array}$ & 28.3 & 30.6 & 43.1 & 6.1 & 0 \\
\hline Cohort 1958-1974 & 46.0 & 22.3 & 16.0 & 7.0 & 0.1 \\
\hline Cohort 1975-1990 & 54.0 & 77.7 & 84.0 & 93.0 & 0.2 \\
\hline $\begin{array}{l}\text { Unskilled blue or white } \\
\text { collar parents }\end{array}$ & 36.8 & 28.3 & 17.6 & 36.9 & 30.2 \\
\hline $\begin{array}{l}\text { Religion rather or very } \\
\text { important }\end{array}$ & 60.1 & 61.1 & 38.0 & 65.8 & 21.6 \\
\hline Less than 2 siblings & 8.7 & 9.2 & 29.5 & 12.7 & 11.7 \\
\hline 2 or 3 siblings & 29.5 & 34.2 & 40.7 & 37.7 & 10.9 \\
\hline 4+ siblings & 61.8 & 56.6 & 29.8 & 49.5 & 13.4 \\
\hline Only foreign language spoken & 11.8 & 10.2 & 18.1 & 51.2 & 20.2 \\
\hline No qualifications & 19.7 & 15.6 & 8.6 & 31.7 & 13.4 \\
\hline Lower vocational education & 21.1 & 15.6 & 9.2 & 22.4 & 20.2 \\
\hline Secondary education & 25.2 & 29.2 & 27.5 & 24.0 & 21.8 \\
\hline Higher education & 34.0 & 39.6 & 54.7 & 21.9 & 44.5 \\
\hline Married & 11.6 & 5.6 & 4.5 & 13.8 & 11.5 \\
\hline Cohabiting & 20.2 & 15.9 & 19.9 & 14.0 & 34.1 \\
\hline Mixed couple & 13.0 & 9.0 & 16.3 & 4.3 & 5.5 \\
\hline No longer in education & 60.4 & 57.4 & 57.2 & 57.4 & 59.1 \\
\hline Stable employment & 39.0 & 25.1 & 25.3 & 26.2 & 47.8 \\
\hline Aged 15-17 & 29.2 & 35.8 & 34.4 & 43.0 & 25.6 \\
\hline Aged 18-21 & 32.5 & 33.2 & 35.8 & 36.9 & 30.2 \\
\hline Aged 22-25 & 20.4 & 17.8 & 19.1 & 13.8 & 21.6 \\
\hline Aged 26-29 & 10.3 & 8.8 & 7.6 & 4.3 & 11.7 \\
\hline Aged 30+ & 7.6 & 4.4 & 3.2 & 2.0 & 10.9 \\
\hline $\mathrm{N}$ of 1st births & 665 & 117 & 67 & 85 & 1,066 \\
\hline $\mathrm{N}$ of 2nd births & 434 & 57 & 30 & 51 & 754 \\
\hline $\mathrm{N}$ of 3rd births & 192 & 19 & 8 & 14 & 265 \\
\hline
\end{tabular}

Source: Calculations based on $\mathrm{TeO} 2008$ 
Figure A-1: Odds of a birth by origin and importance of religion in own education

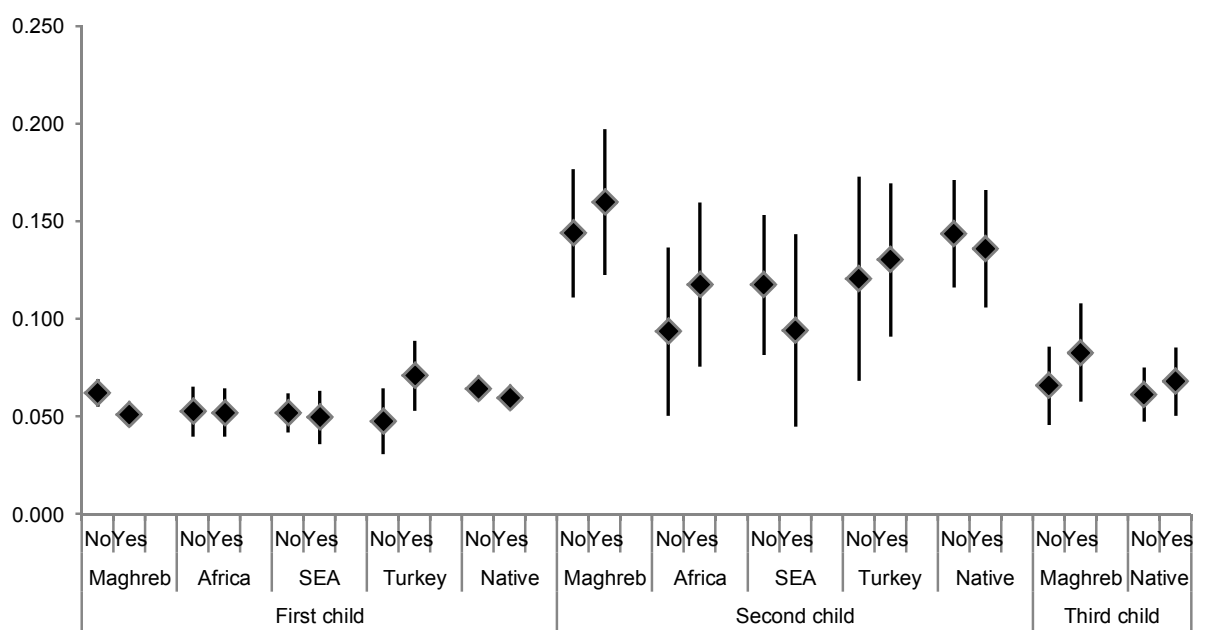


Figure A-2: Odds of a birth by origin and number of siblings

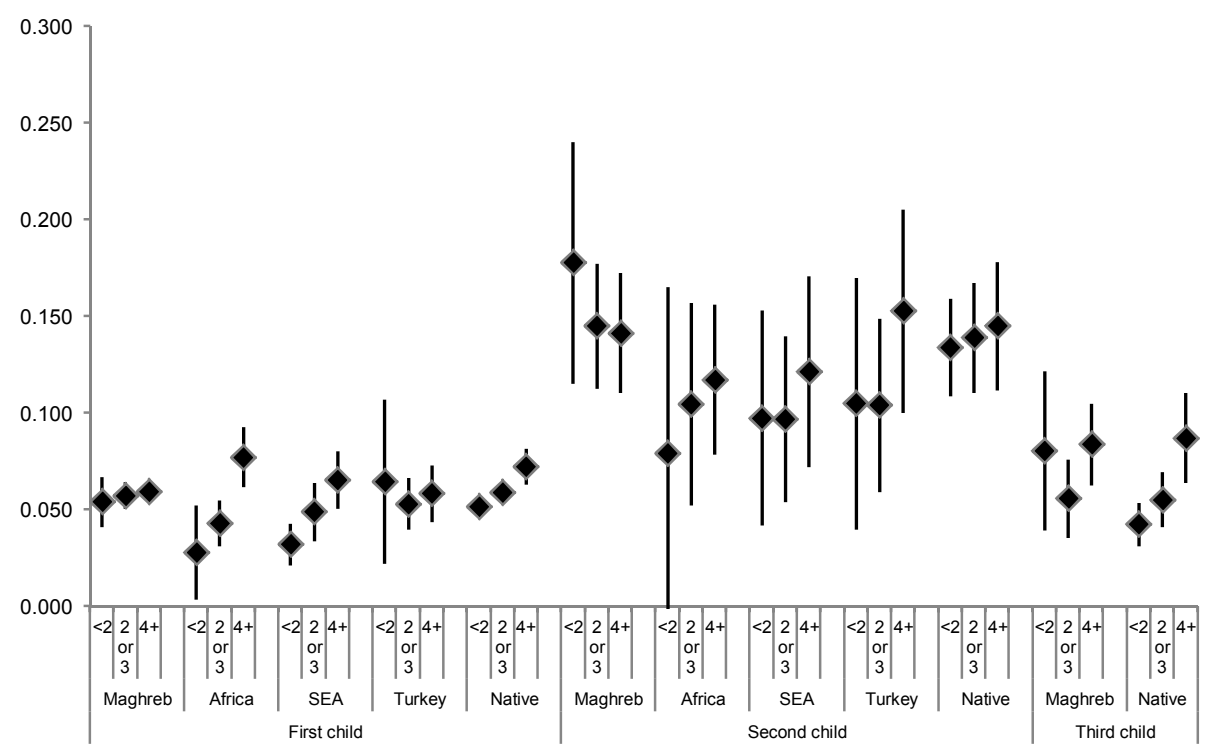


Pailhé: The convergence of second-generation immigrants' fertility patterns in France

Figure A-3: Odds of a birth by origin and education

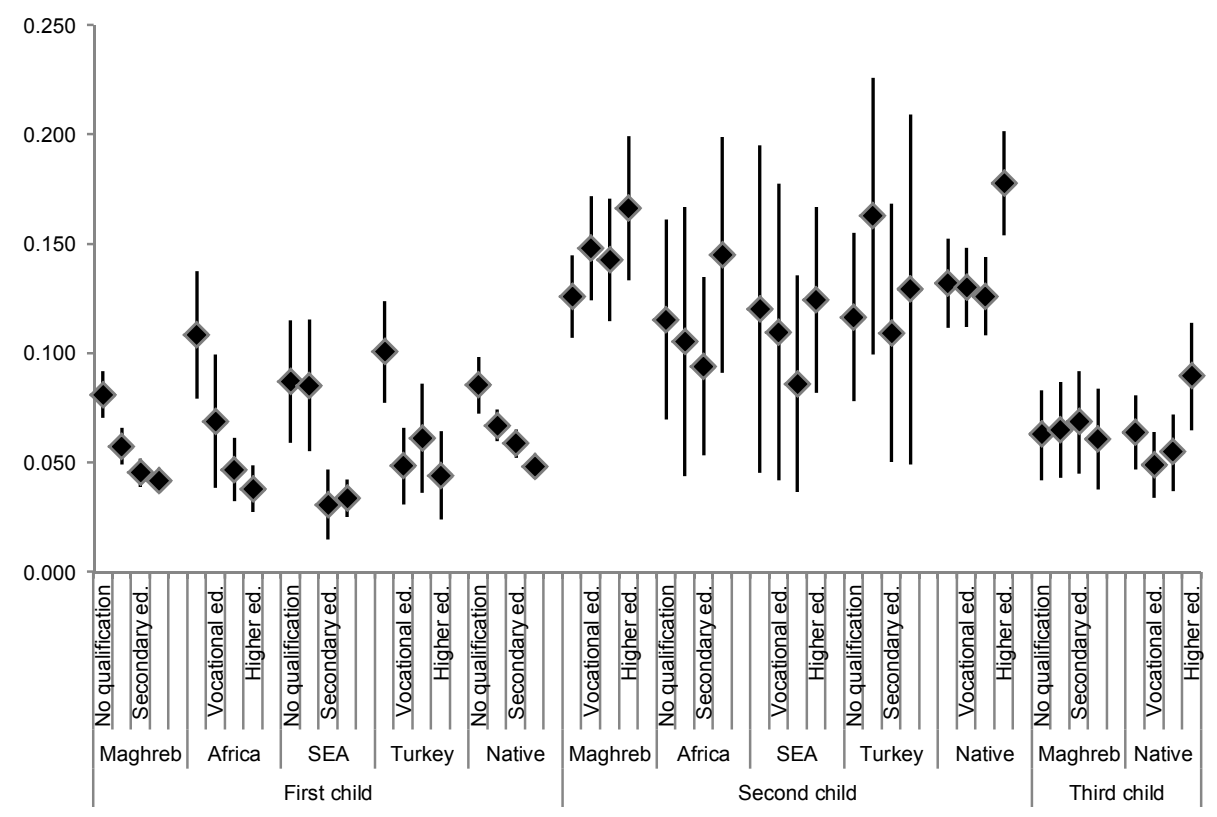

